\title{
DIRECT GENOTOXICITY AND MUTAGENICITY OF ENDODONTIC SUBSTANCES AND MATERIALS AS EVALUATED BY TWO PROKARYOTIC TEST SYSTEMS
}

\author{
GENOTOXICIDADE E MUTAGENICIDADE DIRETAS DE SUBSTÂNCIAS E MATERIAIS \\ ENDODÔNTICOS AVALIADAS POR DOIS TESTES PROCARIOTAS
}

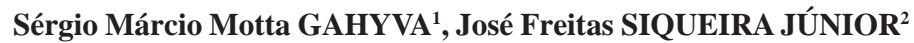

1- DDS, MSc, PhD Adjunct professor, Department of Endodontics, Estácio de Sá University, Rio de Janeiro, RJ, and Department of Dentistry, Nova Friburgo Dental School, Nova Friburgo, RJ.

2- DDS, MSc, PhD, Chairman and professor, Department of Endodontics, Estácio de Sá University, Rio de Janeiro, RJ, Brazil.

Corresponding address: José F. Siqueira Jr - Av. Almte Ary Parreiras 311 / 1001, Icaraí, Niterói, RJ - Brazil - Cep.: 24230-322

Phone: 21 8874-1022 - FAX: 21 2503-7289 ramal 223 - E-mail: siqueira@estacio.br

Received: April 25, 2005 - Modification: June 21, 2005 - Accepted: July 20, 2005

\begin{abstract}
$S$

Substances and materials used in endodontic therapy come into close contact with the periradicular tissues via apical foramen and foramina. Consequently, they should possess biocompatibility. There are currently few studies describing the genotoxic and mutagenic potentials of substances and materials used in endodontics. The purpose of this study was to evaluate the direct genotoxic and mutagenic properties of several substances and materials used in different phases of the endodontic treatment. For this intent, two prokaryotic test systems were used: the SOS chromotest and the Ames test. No metabolization with S9 was investigated, since only the direct effects of the substances and materials were surveyed. Most of the substances and materials tested presented mild to moderate cytotoxicity and genotoxicity as revealed by the SOS chromotest. Formocresol was the only tested substance to present severe genotoxicity to the tester bacterial strains. However, no substance or material tested showed direct mutagenicity as revealed by the Ames test.

Uniterms: Root canal therapy; Intracanal medication; Root canal irrigants; Root canal filling materials; Genotoxycity tests; Mutagenicity tests.
\end{abstract}

\section{RESUMO}

$S$

ubstâncias e materiais utilizados na terapia endodôntica entram em íntimo contato com os tecidos perirradiculares via forame apical e foraminas e, em decorrência disto, deveriam idealmente possuir as seguintes características: biocompatibilidade e ausência de mutagenicidade. Existem poucos estudos avaliando o potencial genotóxico e mutagênico de substâncias e materiais utilizados em Endodontia. Este estudo avaliou os efeitos citotóxicos, genotóxicos e mutagênicos diretos de várias substâncias e materiais utilizados em diferentes etapas do tratamento endodôntico. Para isto, dois sistemas procarióticos foram usados: o SOS chromotest e o teste de Ames. Metabolização com fração S9 não foi realizada, uma vez que tencionou-se avaliar os efeitos diretos das substâncias e materiais. Os resultados demonstraram que algumas substâncias e materiais foram citotóxicos e/ou genotóxicos no SOS chromotest. Formocresol foi a única substância testada a apresentar efeitos genotóxicos severos sobre as cepas teste. Todavia, nenhum dos materiais ou substâncias avaliados apresentou mutagenicidade no teste de Ames.

Unitermos: Tratamento do canal radicular; Medicação intracanal; Irrigantes do canal radicular; Materiais restauradores do canal radicular; Testes de genotoxicidade; Testes de mutagenicidade. 


\section{INTRODUCTION}

Irrigants, medicaments and root filling materials enter into close contact with the periradicular tissues via the apical foramen and occasional lateral foramina. Therefore, an ideal substance or material for endodontic use should be biocompatible with the periradicular tissues ${ }^{16}$.

Prokaryotic test systems have been widely used to investigate the genotoxic and mutagenic potential of substances ${ }^{3,4,20,21}$. Two of the most commonly used prokaryotic assays are the SOS chromotest ${ }^{20,21}$ and the Ames test $^{3,4}$. The SOS chromotest is based on the fact that some of the responses induced by DNA-damaging agents on Escherichia coli involve a set of functions referred to as the SOS response ${ }^{20,21}$. With very few exceptions, most mutagenic genotoxins are also SOS inducers. This method takes advantage of an operon fusion placing $l a c Z$, the structural gene for b-galactosidase, under control of the sfiA gene, and SOS function involved in inhibition of cell division. The $E$. coli PQ37 tester strain used in the SOS chromotest carries a sfiA:lacZ fusion and has a deletion for the normal lac region so that b-galactosidase activity is strictly dependent on sfiA expression. Production and induction of b-galactosidase by the tester strain may be evidenced on indicator plates containing a substrate (Xgal=5-bromo-4chloro-3-indolyl-bD-galactoside), which releases a colored dye when hydrolyzed by b-galactosidase ${ }^{21}$. The Ames test is a mutagenicity test that encompasses the detection of mutations by histidinedependant Salmonella typhimurium strains ${ }^{3,4,17}$. The strains TA 97a, TA 98, TA 100 and TA102 are auxotrophs for histidine (His-) and can revert spontaneously to His + and thus grow in a histidine-free medium. This is a very weak spontaneous reversion, which can however be increased by mutagens. Increased reversion rate allows assessment of the mutagenic potential of these substances ${ }^{17}$.

Little information exists in the literature on potencial genotoxicity and mutagenicity of endodontic substances and materials ${ }^{6-8,11,12,15,18,19,24,25,28}$. The purpose of this study was to examine several substances and materials for direct genotoxic and/or mutagenic potential by the SOS chromotest and the Ames test.

\section{MATERIALS AND METHODS}

\section{Substances}

The following materials and substances were used in this experiment:

1. Camphorated paramonochlorophenol (CMCP) (Biodinâmica Química Farmacêutica Ltda, Ibiporã, PR, Brazil);

2. Formocresol (Biodinâmica Química Farmacêutica Ltda);

3. Calcium hydroxide paste in glycerin;

4. Calcium hydroxide paste in CMCP and glycerin;

5. Calcium hydroxide paste in formocresol and glycerin;

6. $2 \%$ chlorhexidine digluconate ( $\mathrm{CHX}$ ) in natrozole gel containing $15 \%$ zinc oxide;

7. $2 \%$ CHX solution in distilled water;
8. $2 \% \mathrm{NaOCl}$ solution;

9. Zinc oxide/eugenol (ZOE) cement (Super Dentária Napoleão Ltda, Rio de Janeiro, RJ, Brazil);

10. Grossman’s sealer (Fillcanal, Dermo Laboratórios Ltda, Rio de Janeiro, RJ, Brazil);

11. AH Plus sealer (Dentsply DeTrey, Konstanz, Germany);

12. Sealer 26 (Dentsply, Petrópolis, RJ, Brazil);

13. Resin of Sealer 26 (bisphenol A diglycidyl ether).

Calcium hydroxide pastes were prepared by adding the powder to the liquid up to a creamy consistency was achieved. The ratio of CMCP or formocresol and glycerin in pastes 4 and 5 was 1:1 (volume:volume). Sealers were prepared according to the manufacturers' instructions.

\section{SOS chromotest}

Bacterial strains used in the SOS chromotest were $E$. coli PQ35 and PQ37. The assay was performed as described by Quillardet, et al. ${ }^{21}$ (1985). Production and induction of bgalactosidade by the tester strains were determined in plates containing Xgal substrate, which releases a colored tincture when hydrolyzed by b-galactosidade.

Aliquots of $0.1 \mathrm{~mL}$ of an overnight culture of the tester strains were diluted in $5 \mathrm{~mL}$ of LA medium and then incubated under rotation for $2 \mathrm{~h}$ to reach a concentration of $2 \times 10^{8}$ colony forming units/mL. Afterwards, fractions of $0.1 \mathrm{~mL}$ were distributed in assay tubes and $2.5 \mathrm{~mL}$ of molten top agar at $50^{\circ} \mathrm{C}$ was added to each test tube. After agitation, the mixture was poured on ST medium plates. Plates were tilted and rotated to distribute the top agar evenly. Agar was then allowed to set.

All substances and materials tested were diluted in 95\% ethanol (1:1, volume:volume), except for CMCP, formocresol, $\mathrm{NaOCl}$ and $\mathrm{CHX}$ solution, which were used in natura. Eugenol was used as control for the ZOE cement.

After setting of the top agar, $10 \mu \mathrm{L}$ of each tested material or substance were spotted onto the center of the plate. The cytotoxic and genotoxic effects of the substances and materials were assessed after overnight incubation at $37^{\circ} \mathrm{C}$. Evaluation of cytotoxicity was based on the zones of bacterial growth inhibition around the substances. Genotoxicity was evaluated on the basis of the colorimetric intensity of a blue ring formed around the zone of inhibition. Both genotoxic and cytotoxic effects were ranked as absent, mild, moderate, and severe. 4-nitroquinoline-1-oxide (4NQO) was used as positive control, while dimethyl sulfoxide (DMSO) and 95\% ethanol were used as negative controls.

\section{Ames test}

S. typhimurium strains TA98, TA97a, TA100 and TA102 were used in this test. Cultures of these strains grown overnight were checked for confirmation of the following features: $r f a$ and $u v r B$ mutation, presence of the plasmids pKM101 (resistance to ampicillin) and pAQ1 (resistance to tetracycline), dependence on hystidin, and spontaneous reversal rate. The assay used was the spot test as described 
by Maron and Ames ${ }^{17}$ (1983).

Strains stored in liquid nitrogen were thawed and then grown overnight in Oxoid nutrient broth \#2 up to a density of $1-2 \times 10^{9} \mathrm{CFU} / \mathrm{mL}$. All substances and materials were diluted in 95\% ethanol, except for CMCP, formocresol, $\mathrm{NaOCl}$ and CHX solution, which were used in natura. Positive controls consisted of 4-NQO, a recognized mutagenic substance, while negative control was represented by DMSO.

Briefly, $100 \mathrm{~mL}$ of each bacterial strain were mixed with molten top agar (0.55\% agar, 0.55\% NaCl, 50 mM L-histidine, $50 \mathrm{mM}$ biotin, $\mathrm{pH} 7.4,45^{\circ} \mathrm{C}$ ) in a final volume of $3 \mathrm{~mL}$. Each mixture was then poured onto the minimal agar plates $(1.5 \%$ agar, Vogel-Bonner E medium, with $2 \%$ glucose). After a few minutes, paper discs moistened with $10 \mu \mathrm{L}$ of the liquid substances tested were placed onto the top agar surface. Ten microliters of the pastes were spotted directly on the plates. Plates were then incubated at $37^{\circ} \mathrm{C}$ for 72 hours.

Controls were performed in triplicate, while experiments using the test substances were performed in duplicate. Mutagenicity was determined by the density of colony forming units around the substances and materials and classified as absent, mild, moderate, or severe.

\section{RESULTS}

\section{SOS Chromotest}

The substance 4NQO, used as positive control, showed sfiA::lacZ induction characterized by an intense blue ring around the substance (Figure 1), while no effects were observed for DMSO and 95\% ethanol (negative controls). Among the several test substances and materials, some showed zones of growth inhibition (cytotoxicity) and/or sfiA::lacZ induction (genotoxicity). $\mathrm{NaOCl}$ showed moderate cytotoxicity to both strains, and moderate genotoxicity to strain PQ37. Chlorhexidine was mildly cytotoxic and moderately genotoxic to strain PQ37. When this substance was mixed with zinc oxide, it showed mild cytotoxicity and genotoxicity to strain PQ35 (Figure 2), and mild citotoxicity and moderate genotoxicity to strain PQ37. CMCP was mildly cytotoxic and moderately genotoxic to strain PQ35, while it induced moderate cytotoxicity and genotoxicity to strain PQ37. Cytotoxicity of formocresol was moderate to strain PQ37, but severe to PQ35. Genotoxicity was severe to both strains (Figure 3). Calcium hydroxide pastes in formocresol or CMCP were moderately genotoxic to strain PQ35. Calcium hydroxide in glycerin, ZOE cement, AH Plus and Sealer 26 did not show any cytotoxicity or genotoxicity to the test strains. Sealer 26 resin showed no effects on PQ37, but it was mildly genotoxic to strain PQ35. Grossman's sealer showed mild cytotoxicity only to strain PQ35, but no genotoxicity was observed. Results are detailed in Table 1.

\section{Ames test}

The substance 4NQO, used as positive control, induced a large increase in the number of revertant colonies characterized by a ring of colonies around the substance (Figure 4). No increase in the number of revertants occurred for DMSO (negative control). No test substance or material exhibited mutagenic potential to any of the $S$. tiphymurium strains used in this study (Figure 5).

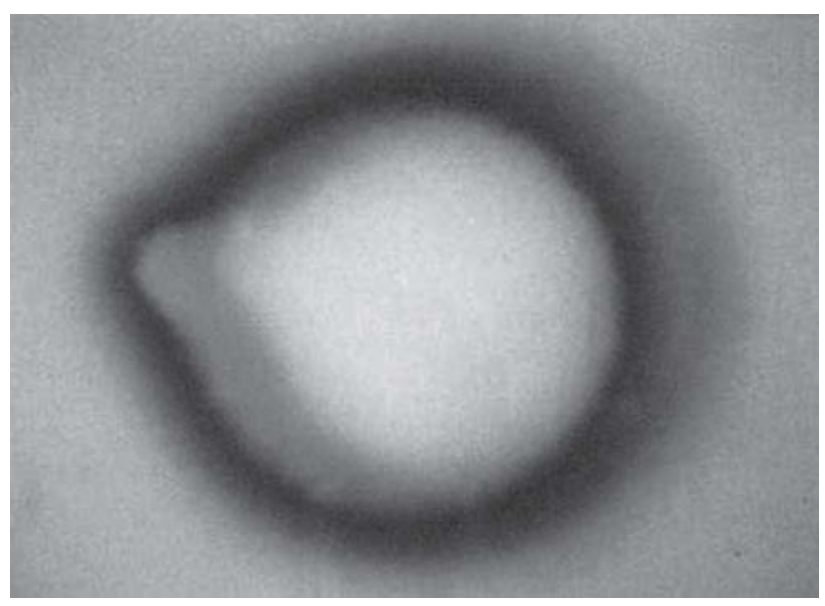

FIGURE 1- Intense blue ring around the test substance indicating genotoxicity in the SOS chromotest. Positive control with 4NQO against strain PQ37

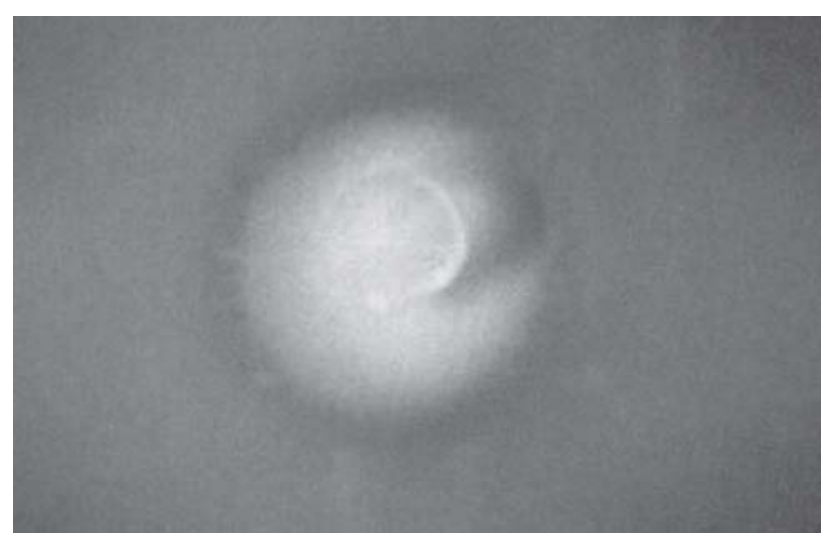

FIGURE 2- Mild genotoxicity of chlorhexidine gel containing zinc oxide against strain PQ35 in the SOS chromotest

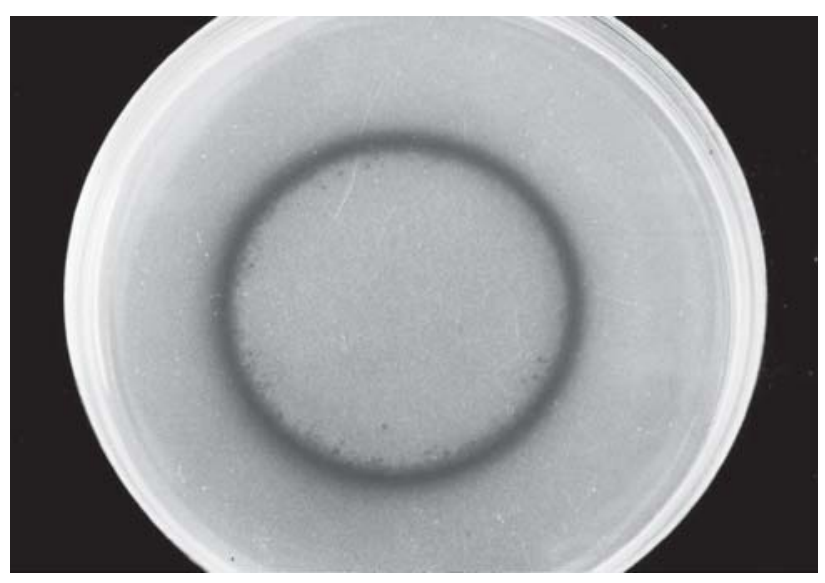

FIGURE 3- Severe genotoxicity of formocresol against strain PQ37 in the SOS chromotest 


\section{DISCUSSION}

In this study we used two prokaryotic tests to check for the direct genotoxicity and mutagenicity of substances and materials commonly used in endodontic practice. Data on these characteristics of endodontic substances and materials are scarce in the literature and this study attempted to lend additional knowledge on the subject. Even though genotoxicity and mutagenicity tests using mammalian cells

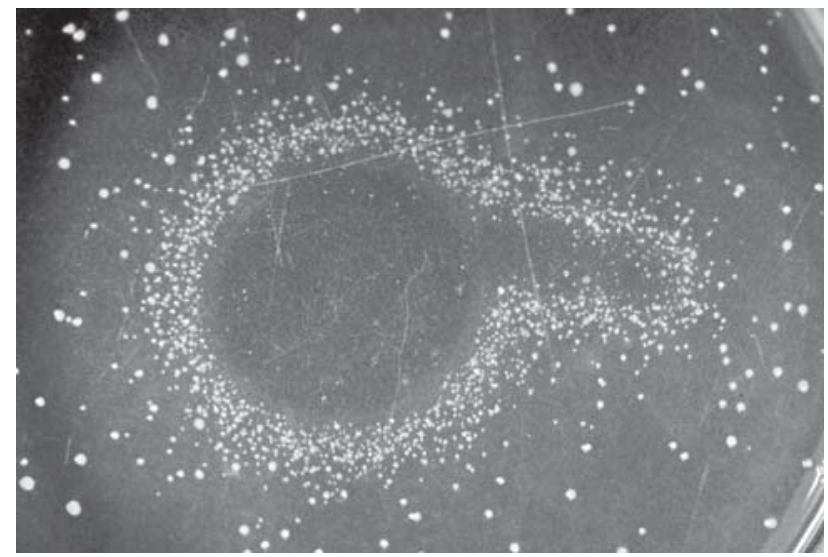

FIGURE 4- Increase in the number of revertants forming a ring of colonies around the test substance indicating mutagenicity in the Ames test. Positive control with 4NQO against strain TA100 are theoretically more relevant than prokaryotic systems, the latter have been widely used and are commonly accepted for screening of the genotoxic and mutagenic potential of substances. These short-term prokaryotic tests can detect potentially dangerous chemicals and indicate priorities for further testing.

The SOS chromotest was performed with both PQ35 and PQ37 strains with the purpose to investigate whether the materials and substances were able to induce a SOS response,

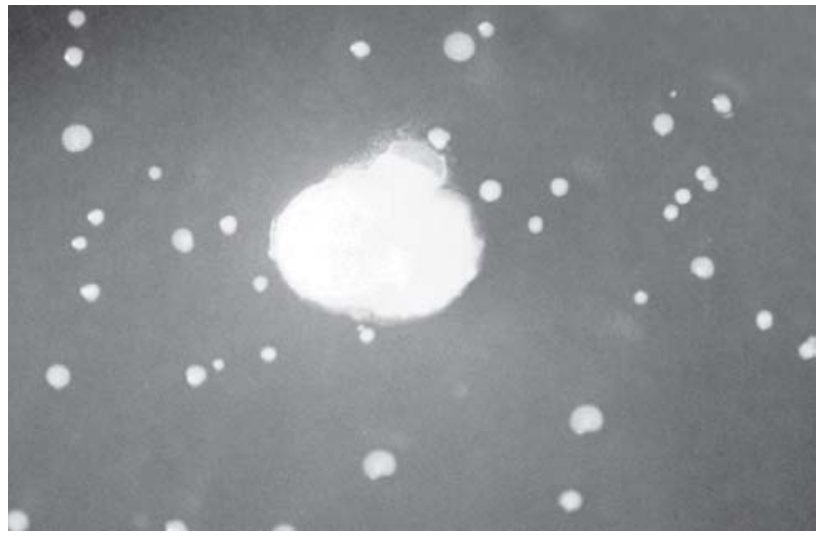

FIGURE 5- Absence of mutagenicity for the calcium hydroxide paste in camphorated paramonochlorophenol in the Ames test. Representative plate using strain TA98

TABLE 1- Results of the SOS chromotest for evaluation of the cytotoxic and genotoxic potential of different endodontic substances and materials

Cytotoxicity Genotoxicity Cytotoxicity Genotoxicity

\begin{tabular}{|c|c|c|c|c|}
\hline $\mathrm{Ca}(\mathrm{OH})_{2} /$ glycerin & - & - & - & - \\
\hline $\mathrm{Ca}(\mathrm{OH})_{2} / \mathrm{CMCP} / g l y c e r i n$ & - & ++ & - & - \\
\hline $\mathrm{Ca}(\mathrm{OH})_{2} /$ formocresol/glycerin & - & +++ & - & - \\
\hline ZOE cement & - & - & - & - \\
\hline Eugenol & + & - & + & + \\
\hline AH Plus & - & - & - & - \\
\hline Sealer 26 & - & - & - & - \\
\hline Sealer 26 resin & - & + & - & - \\
\hline Grossman's sealer & + & - & - & - \\
\hline CMCP & + & ++ & ++ & ++ \\
\hline Formocresol & ++++ & ++++ & +++ & ++++ \\
\hline $\mathrm{NaOCl}$ & ++ & - & +++ & ++ \\
\hline Chlorhexidine & NT & NT & + & +++ \\
\hline Chlorhexidine/zinc oxide & + & + & + & +++ \\
\hline 4NQO (positive control) & ++++ & ++++ & ++++ & ++++ \\
\hline DMSO (negative control) & - & - & - & - \\
\hline
\end{tabular}

Absent - ; Mild +; Moderate ++ to +++; Severe ++++

$\mathrm{CMCP}$, camphorated paramonochlorophenol; ZOE, zinc oxide/eugenol cement; NT, not tested. 
which is induced by damage that blocks DNA synthesis. To determine whether the bacterial damage induced by the materials and substances tested leads to mutation, the $S$. typhimurium reverse mutagenesis test (Ames test) was also employed. For a given substance to yield positive results in the Ames test, it has to induce a significant increase in the number of revertants as compared to negative controls in at least two independent assays (duplicate) ${ }^{17}$. A positive response is considered when the increase in the number of revertants around the test substance is higher than or equal to the double of the number of spontaneous revertants ${ }^{30}$.

The capacity of the Ames test to identify carcinogens is higher than that of the SOS chromotest ${ }^{17,22}$. However, because the number of false positive compounds is usually lower in the SOS chromotest, the specificity, i.e., the capacity to discriminate between carcinogens and non-carcinogens of the SOS chromotest, appears to be higher than that of the Ames test ${ }^{20-22}$. Thus, the results of the SOS chromotest and of the Ames test can complement each other. The SOS chromotest is one of the most rapid and simple short-term test for genotoxins and is easily adaptable to diverse conditions, so that it can be used as an early test in a battery ${ }^{22}$.

Chemicals that initiate carcinogenesis are extremely diverse in structure and include both natural and synthetic products. They can be divided into two categories: directacting compounds, which do not require chemical transformation for their carcinogenicity, and indirect-acting compounds, which require conversion by mammalian metabolism ${ }^{2}$. Incubation of substances with a rat liver homogenate has been proposed to supply mammalian metabolism in the test and activate potential indirect-acting carcinogens ${ }^{2}$. All experiments in the present study were carried out in the absence of exogenous metabolic activation (S9) due to the fact that the substances and materials tested are used in direct contact with a small host tissue area. Therefore, our results are related to the direct genotoxicity and mutagenicity of endodontic substances and materials. In fact, most of the mutagenic effects reported for some endodontic materials were observed without S9 activation ${ }^{11,19,28}$. Further additional studies are required to investigate their indirect effects after metabolization.

While the zinc oxide-eugenol cement showed no toxicity to the strains tested, eugenol alone induced the sfiA::lacZ fusion in PQ37 strain. This corroborates the findings from other studies ${ }^{13,21}$, which demonstrated that eugenol can be cytotoxic, but not mutagenic. Also Stea, et al. ${ }^{28}$ (1994) investigated the mutagenic potential of some endodontic sealers through the Ames test and showed that zinc oxideeugenol cement was toxic against strain TA100, but lacked mutagenicity. They also observed that calcium hydroxidecontaining sealers had a low cytotoxic potential and absence of mutagenicity. This is also in accordance with our findings.

Jukic, et al. ${ }^{11}$ (2000) observed that AH Plus was mutagenic toward strain TA100 without S9 one hour after mixing. One month after mixing, mutagenic activity was expressed only in TA98. AH26 was mutagenic to TA100 without S9 immediately after mixing, one hour later, and one month after it was polymerized. Schweikl and Schmalz ${ }^{25}$ (1991) demonstrated mutagenicity for freshly mixed AH26. In the present study, neither AH Plus sealer nor Sealer 26, which is a derivative of AH 26, presented genotoxic or mutagenic effects. Our findings are in consonance with Leyhausen, et al. ${ }^{15}$ (1999), who found no such adverse effects for the resin of the AH Plus sealer. In regard to Sealer 26, it is possible that addition of calcium hydroxide to the sealer's formulation can diminish toxic effects, but further studies should confirm this assumption.

Of the tested substances and materials, formocresol was the only one that showed severe genotoxicity in the SOS chromotest. It is well known that formaldehyde (a component of formocresol) is highly cytotoxic, genotoxic, mutagenic and carcinogenic ${ }^{5,14,23}$. Mutagenic properties of formaldehyde are usually associated with its ability to form adenine dimers through methylene bridges ${ }^{14}$. Even though no mutagenic effects were observed for formocresol on Salmonella strains in the Ames test used in this study, data are not conclusive. It has been reported that the results with formaldehyde in the Ames test are somewhat conflicting ${ }^{19}$. Detection of formaldehyde as a mutagen in the Ames test can be hampered by the high toxicity of the substance toward the test bacteria, leaving only a narrow dose range for mutagenicity detection. In addition, the high volatility of formaldehyde can also account for some of the negative results ${ }^{19}$. In our opinion, because of its high genotoxicity as demonstrated in this study and the mutagenic activity as shown by others ${ }^{14,23}$, the use of formaldehyde-containing substances should be discontinued in endodontic therapy.

CMCP was moderately genotoxic in the SOS chromotest. Both cytotoxic and genotoxic effects of formocresol and CMCP when associated with calcium hydroxide were reduced or abolished in comparison with the substances alone. These results are possibly related to the fact that CMCP or formocresol are slowly released from the paste with calcium hydroxide, and in lower concentrations. These findings are in agreement with previous studies showing that association of CMCP with calcium hydroxide in a paste can reduce the toxic effects of the former ${ }^{13,29}$, while maintaining excellent antimicrobial activity ${ }^{26,27}$.

Under normal treatment conditions, endodontic substances and materials enter into contact with the periradicular tissues through a small area and, except for rootfilling materials, for a short time period. Thus, it is highly unlikely that these substances will induce significant damage to the tissues provided their use is restricted to the confines of the root canal system ${ }^{9,10}$. In the event of extrusion of these substances into the periradicular tissues, a larger contact area is established and undesirable effects can ensue, such as cytotoxicity and genotoxicity.

\section{CONCLUSIONS}

Some tested substances showed cytotoxicity and genotoxicity to the strains used in the SOS chromotest. However, these effects were not pronounced, except for formocresol, which was highly cytotoxic and genotoxic to the tester strains. No substance or material presented direct 
mutagenicity without S9 activation in the Ames test. Even so, the use of highly cytotoxic and genotoxic substances in endodontic therapy should be avoided to prevent adverse reactions of the periradicular tissues that could put in risk the outcome of the treatment. Further studies using a large battery of tests, metabolization approaches, and eukaryotic systems are required before safety for using these substances and materials can be assured.

\section{ACKNOWLEDGEMENTS}

This paper was part of the PhD Thesis of Dr. Sérgio M. Gahyva. Unfortunately, Dr. Gahyva has passed away during the preparation of this manuscript. Thus, this paper is dedicated to the memory of this excellent endodontist who, above all, was a great friend (JSFJ).

\section{REFERENCES}

1- Allavena A, Martelli A, Robbiano L, Brambilla G. Evaluation in a battery of in vivo assays of four in vitro genotoxins proved to be noncarcinogens in rodents. Teratog Carcinog Mutagen. 1992;12:3141 .

2- Ames BN, Durston WE, Yamasaki E, Lee FD. Carcinogens are mutagens: a simple test system combining liver homogenates for activation and bacteria for detection. Proc Natl Acad Sci USA. 1973;70:2281-5.

3- Ames BN, Lee FD, Durston WE. An improved bacterial test system for the detection and classification of mutagens and carcinogens. Proc Natl Acad Sci USA. 1973;70:782-6.

4- Ames BN, Mccann J, Yamasaki E. Methods for detecting carcinogens and mutagens with the Salmonella/mammalian-microsome mutagenicity test. Mutat Res. 1975;31:347-64.

5- Auerbach C, Moutschen-Dahmen M, Moutschen J. Genetic and cytogenetical effects of formaldehyde and related compounds. Mutat Res. 1977;39:317-61.

6-Chang YC, Huang FM, Cheng MH, Chou LS, Chou MY. In vitro evaluation of the cytotoxicity and genotoxicity of root canal medicines on human pulp fibroblasts. J Endod. 1998;24:604-6.

7- Chang YC, Tai KW, Huang FM, Huang MF. Cytotoxic and nongenotoxic effects of phenolic compounds in human pulp cell cultures. J Endod. 2000;26:440-3.

8- Geurtsen W, Leyhausen G. Biological aspects of root canal filling materials-histocompatibility,cytotoxicity, and mutagenicity. Clin Oral Investig. 1997;1:5-11.

9- Harrison JW, Baumgartner JC, Svec TA. Incidence of pain associated with clinical factors during and after root canal therapy. Part 1. Interappointment pain. J Endod. 1983;9:384-7.

10- Harrison JW, Svec TA, Baumgartner JC. Analysis of clinical toxicity of endodontic irrigants. J Endod. 1978;4:6-11.

11- Jukic S, Miletic I, Anic I, Britvic S, Osmak M, Sistig S. The mutagenic potential of AH Plus and AH26 by salmonella/microsome assay. J Endod. 2000;26:321-4.
12- Kettering JD, Torabinejad M. Investigation of mutagenicity of mineral trioxide aggregate and other commonly used root-end filling materials. J Endod. 1995;21:537-9.

13- Leonardo MR, Silva LAB, Utrilla LS, Leonardo RT, Consolaro A. Effect of intracanal dressings on repair and apical bridging of teeth with incomplete root formation. Endod Dent Traumatol. 1993;9:2530

14- Lewis BB, Chestner SB. Formaldehyde in dentistry: a review of mutagenic and carcinogenic potential. J Am Dent Assoc. 1981;103:42934

15- Leyhausen G, Heil J, Reifferscheid G, Waldmann P, Geurtsen W. Genotoxicity and cytotoxicity of the epoxy resin-based root canal sealer AH plus. J Endod. 1999;25:109-13.

16- Lopes HP, Siqueira JF Jr. Endodontia. Biologia e técnica. $2^{\text {a }}$ ed, Rio de Janeiro: MEDSI/Guanabara Koogan; 2004.

17- Maron MD, Ames BN. Revised methods for Salmonella mutagenicity test. Mutat Res. 1983;113:173-215.

18- Maura A, Pino A, Ricci R. Negative evidence in vivo of DNAdamaging, mutagenic and chromosomal effects of eugenol. Mutat Res. 1989;227:125-9.

19- Ørstavik D, Hongslo JK. Mutagenicity of endodontics sealers. Biomaterials. 1985;6:129-32.

20- Quillardet P, Bellecombe C, Hofnung M. The SOS Chromotest, a colorimetric bacterial assay for genotoxins: validation study with 83 compounds. Mutat Res. 1985;147:79-95.

21- Quillardet P, Hofnung M. The SOS Chromotest, a colorimetric bacterial assay for genotoxins: procedures. Mutat Res. 1985;147:6578

22- Quillardet P, Hofnung M. The SOS chromotest: a review. Mutat Res. 1993;297:235-79.

23- Sasaki Y, Endo R. Mutagenicity of aldehydes in Salmonella. Mutat Res. 1978;54:251-2.

24- Schweikl H, Schmalz G, Stimmelmayr H, Bey B. Mutagenicity of AH26 in an in vitro mammalian cell mutation assay. J Endod. 1995;21:407-10.

25- Schweikl H, Schmalz G. Evaluation of the mutagenic potential of root canal sealers using the salmonella/microsome assay. J Mater Sci Mater Med. 1991;2:181-5.

26- Siqueira JF Jr, Uzeda M. Disinfection by calcium hydroxide pastes of dentinal tubules infected with two obligate and one facultative anaerobic bacteria. J Endod. 1996;22:674-6.

27- Siqueira JF Jr, Uzeda M. Influence of different vehicles on the antibacterial effects of calcium hydroxide. J Endod. 1998;24:663-5.

28- Stea S, Savarino L, Ciapetti G, Cenni E, Stea S, Trotta F, Morozzi G, Pizzoferrato A. Mutagenic potential of root canal sealers: evaluation through Ames testing. J Biomed Mater Res. 1994;28:319-28.

29- Torneck CD, Smith JS, Grindall P. Biologic effects of endodontic procedures on developing incisor teeth. IV. Effect of débridement procedures and calcium hydroxide-camphorated parachlorophenol paste in the treatment of experimentally induced pulp and periapical disease. Oral Surg Oral Med Oral Pathol. 1973;35:541-54.

30- WHO - Word Health Organization. Guide to short-term tests for detecting mutagenic and carcinogenic chemicals. Enviromental Health Criteria, Geneva; 1985. 